\title{
EDUCATIONAL ASPECTS OF STUDIES OF CADASTRAL VALUE'S INFLUENCE ON PROPERTY TAXATION AND ACCOUNTING
}

\author{
Yulija Konstantinovna Kharakoz \\ Associate Prof., Diplomatic Academy of the Ministry of Foreign Affairsof the Russian Federation, \\ Russian Federation, pmantonio65@gmail.com
}

\begin{abstract}
International practical approaches towards property taxation are based on the key elements - the taxation object, the taxation base and the tax rate. At that, some countries use the cadastral value as the basis for taxation of some real estate. At the same time the experience of uniting the cadaster services, registration and valuation organizations demonstrates that it helps social development of property relations in a state. This means better state regulation of valuation activities and the establishment of a basic cadastral value of property. At that, the time of cadastral value revision should primarily be based on the country's inflation rate and be adjusted to the market trends taking into account an independent approach towards valuation. This is why the property taxes in most states are a significant source of budget revenue. At the same time when regulating the cadastral value, which is directly linked with the size of the taxation object one should correlate the current economic situation and households' real disposable income, especially during the COVID-19 pandemic. Of course, at the current economic development stage of the countries and the state the tax payers are in maintaining a balance of interests of the state and all economic subjects is important.
\end{abstract}

At that, each state develops its own real estate taxation ways dynamically linking them with the state's interests, the interest of the tax payers and using different methods and mechanisms to make the taxes perform all their functions. Undoubtedly, when working on progressive property taxes developed with the help of the education process, it is important to be based on the use of both sample and historical principles, which help us maintain a balance between the state interests and real life.

Keywords: education, property taxes, market value

\section{INTRODUCTION}

The problems of establishing a property value in the interests of a state is common for many countries. At that, the key objective is to streamline accounting of both subjects and objects when establishing the cadastral value and registration of deals, because they are of a direct influence on the property taxation base (Bliemer, 2017, p.56). At that, the cadastral value established with the help of this mechanism can be disputed both by the property owners and by the government. This is why the necessity of taxing estate and the reasons behind establishing the taxation object and the tax rate is an important issue for discussion 
(Moeslund, 2011, p. 471). At the same time, in real life a reasonable definition of the mandatory elements of real estate taxes is indisputable.

\section{THEORETICAL BACKGROUND}

\subsection{Literature Review}

Economists have varying classifications and order of establishing property value for taxation purposes. For example, some countries use non-market methods in the form of a fixed value (Zvereva, 2020 p, 45), while the states with market economies base them on a cadastral value (Aghaei, 2020, p.1391).

The cadastral system can be broken into the following groups according to their special features. The first group of states (France, Greece, Italy) split their systems into a land cadaster and property registers by the level of lands (city, rural), and by identification of owners, mapping systems and plot valuation. The second group comprising the Scandinavian states is conspicuous for a centralized title register owned by the central government, while the local governments manage information about real estate and mapping (Wang, 2017, p.600). Another group, including the Anglo-Saxon states, is conspicuous for the absence of a land cadaster as an independent object of registration (Chaykovskaya, 2020, p. 163) and the presence of cooperation between the cadaster, mapping and registration system in a unified register of owners.

\subsection{Data Analysis}

Practical approaches towards property taxation is used in all countries of the world, but each has its special features. At the same time, property is one of the primary taxation elements historically followed by other ways of establishing of a taxation object, including sales and profit (the end result is profit received). Analysis of real estate taxation in some countries of the world allowed us to reveal the key special features, which lay the basis of basic approaches of the fiscal order:

1) The level of property tax recipients - this is usually local taxation, which forms budgets of the local governments. In some cases, the tax goes to the federal budgets, but it is later redistributed to the regional or local budgets to finance their needs (Akhmadeev, 2019, p.1149).

2) The taxation objects as a rule include land, buildings and its parts, while the tax payers are property owners (Kalacheva, 2019, p. 4515).

We should note that some states can include objects which are not real estate, such as materials, intangibles, low-value and short-life products, work in progress and even deferred costs, including advance payments for future magazine subscriptions in the property tax objects (Morozova, 2020, p. 2196; Turishcheva, 2020, p. 53). In Russia, the property tax objects include not only land and buildings, but also their parts and any other property, which civil legislation deems as estate as well as any other property with signs of inseparability from the land or other signs at the discretion of the tax authorities.

We should note different approaches towards establishing the taxation base for the property tax. The basis of the method of choice is always the principle of fair, not historical value. For instance, most E.U. states use the market value of real estate as the basis, Great Britain uses the rent value (Voronova, 2020, p. 2; Morozova, 2019, p. 4723), Sweden uses capitalized (accumulative) property value, Moldova and Spain use an estimated value of property, Russia uses the cadastral estate value (Golubtsova, 2019, p. 2023).

Market property value is a possible sales price of an object. Rent value is a possible price of renting out an object, which should be higher than the market sales price because of the duration of deriving revenue. A capitalized (accumulative) property value is a value which includes not only the current market value with a rate of return, but also the possibility of an object to generate future profits, which is why, for instance, the working life, economic prospects of a region, location, etc. can be taken into account.

An estimated value is a value calculated solely with the taxation aims by the authorized organizations, for example, by the tax bodies or specially accredited independent appraisers (Gorlanov, 2019, p. 5293). A Russian cadastral value is a value set by the RosReestr register, which is used for any purpose, including taxation.

In their turn, the tax rates and methodology of their establishment mainly coincide in many states. The highest rate is set at the federal level, while the exact value of the tax is established locally, i.e. at the level of the funds' recipients (Zaporozhtseva, 2020; Avvakumova, 2020, p. 562).

At the same time the tax rate on company property vary strongly from country to country, but to determine its significance it is also necessary to take into account the tax base applied in the country under analysis. 
Thus, the property tax amounts to $5 \%$ in Austria, $1 \%$ in Germany, $0.15 \%$ in Bulgaria, $2.5 \%$ in Sweden, and it cannot exceed $2 \%$ in Russia (Dück, 2015, p. 101). However, in some states the rate can differ - be progressive depending on the type of property, be different sizes for commercial and non-commercial estate.

We should note that property tax benefits are of three types in all the countries - tax reliefs on some types of property, in some regions, for some types of operations. In these cases, the property tax has restraining and stimulating functions, respectively.

At that, tax reliefs on an only small-size housing in ownership of the poor helps maintain their income level thanks to reliefs on tax spending. Tax exemptions in a region help it attract investors and businessmen to economic development. Tax exemptions for agricultural organizations, as low-income organizations with state support, for example, help support the sector.

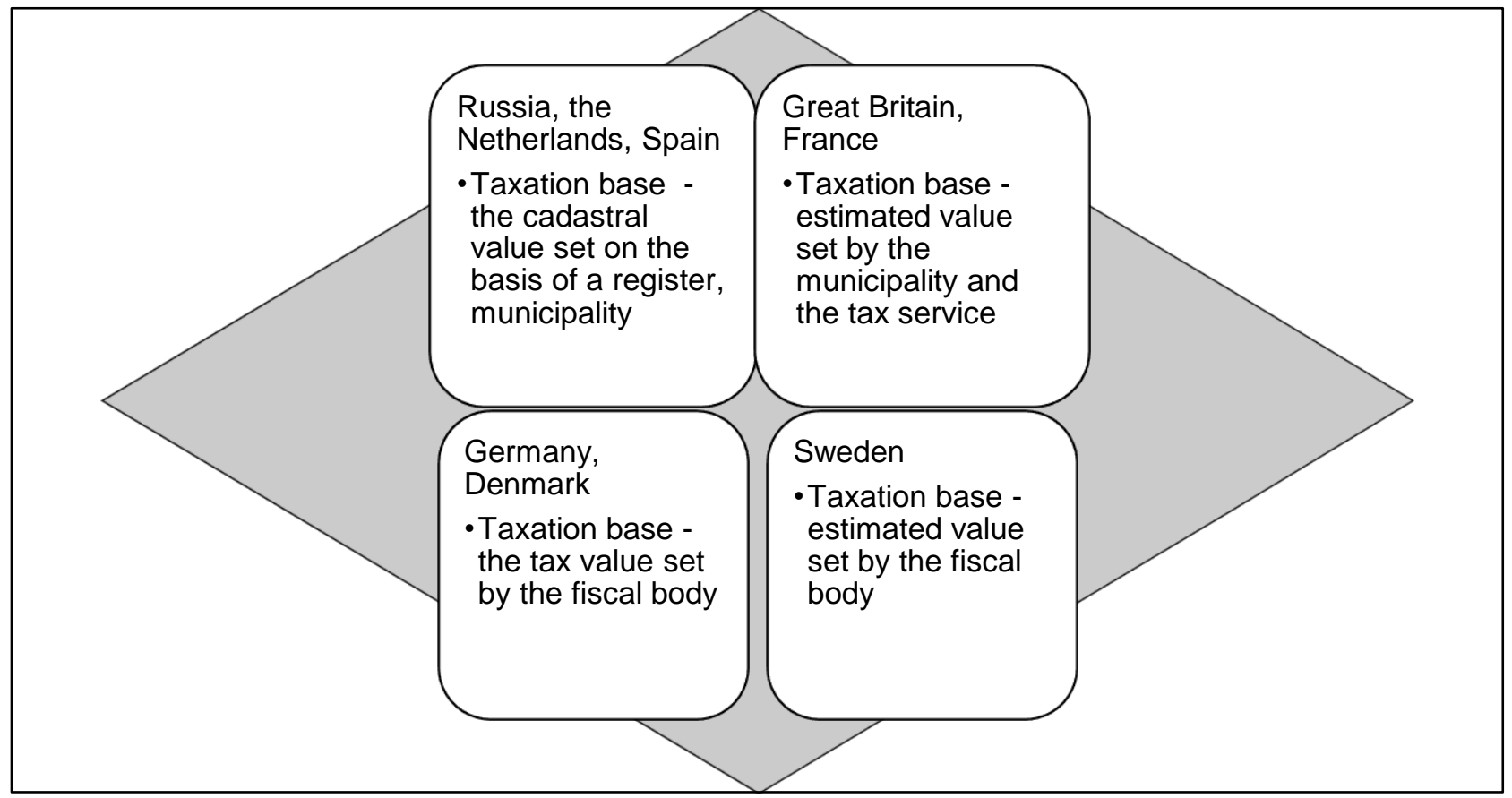

Religious objects and cultural sites traditionally have property tax reliefs. In some cases, the governments offer reliefs on the objects used for educational and social purposes. Some countries, for example, Germany and Canada, use reliefs in the form of tax exempt minimums, depending on the size of property of the poor and families with many children and depending on all property indicators of private practitioners (Golubtsova, 2019, p. 782). In Austria and Switzerland there are no tax exempt minimums, however, property taxation of the aforementioned categories depends on other taxes, for instance, when paying a property tax you are exempt from the income tax in Denmark (Akhmadeev, 2019, p. 766). This is why filling of the local budgets with the property tax of individuals in different countries is presented in Figure 1.

Fig.1. Comparative characteristics of the property tax base by country

\section{RESULTS AND DISCUSSION}

We should note that in the countries under research the property tax is the backbone of municipal budgets and is a powerful lever of infrastructure development by ensuring a sustainable cash flow, which helps attract investment. A special feature of taxes on individuals is a lesser share of income from the property tax to the local budgets than the share of the property taxes paid by the companies (Dück, 2017, p. 260). At the same time the experience of the countries under research demonstrates that the property tax on individuals can account for a significant share of revenue of the state coffers. In this case, the tax rates vary as a rule. For example, Russia's effective property tax for individuals range as follows:

a) $0.1 \%$ for residential houses, their parts as well as rooms, apartments and other objects of uncompleted construction, unified estate complexes, which include at least one apartment house; garages and car places, commercial buildings or structures, whose area does not exceed 50 sq. metres;

b) $2 \%$ for the objects whose cadastral value does not exceed U.S. $\$ 4.25 \mathrm{mln}$.; 
c) $0.5 \%$ for other taxable objects.

At the same time each government develops its own property taxation ways dynamically linking them with the state interests, the interests of the tax payers using different methods and mechanisms to make the tax perform all its functions. Of course, progressive mechanisms of establishment the taxation bases and rates developed with the help of mathematic methods should be applied in taxation, but the use of these sample and historical principles maintains a balance between financial exhibitors and real life.

\section{CONCLUSION}

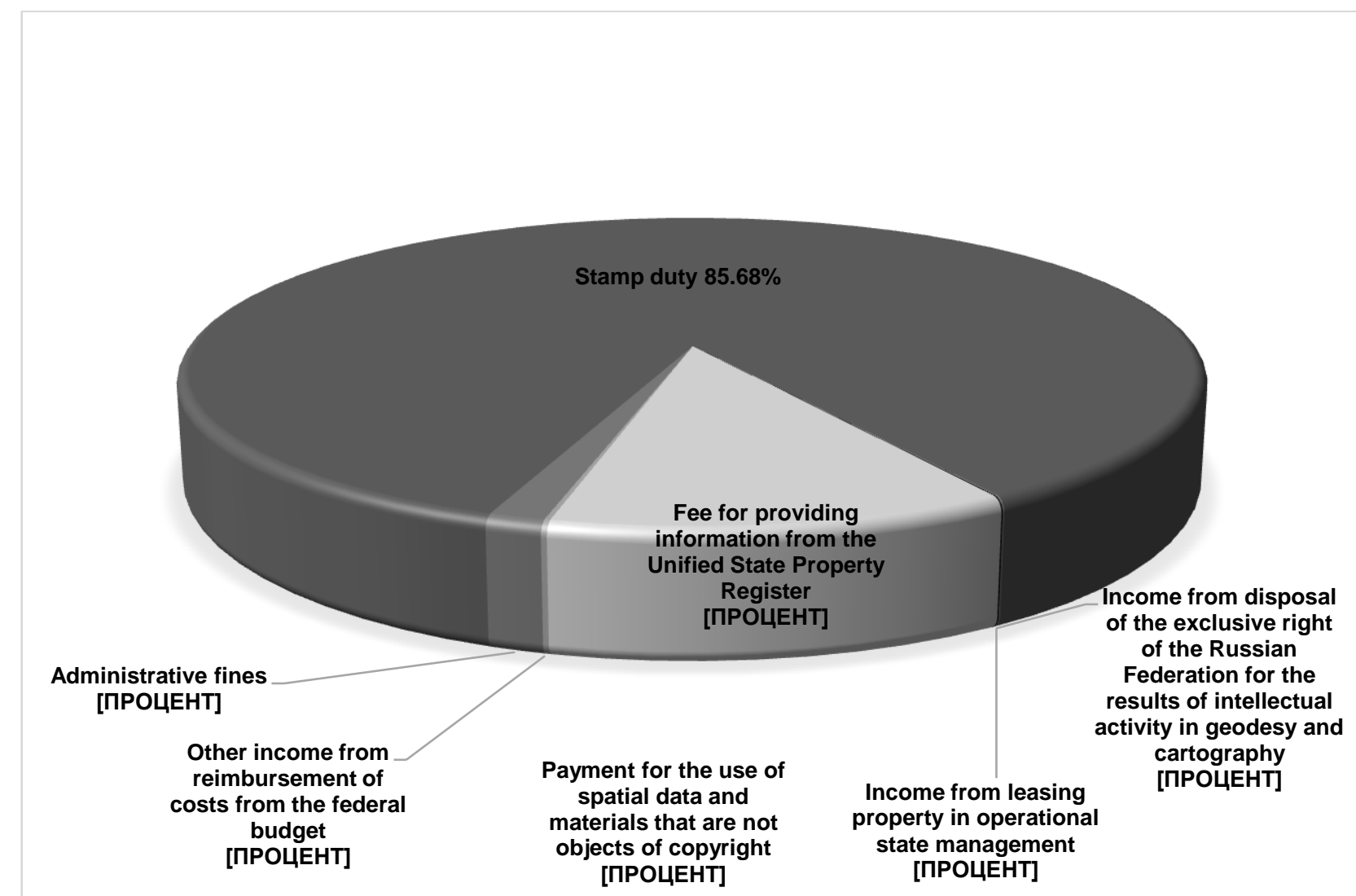

Concentration of information on the cadastral estimates and property rights in one place is optimal for streamlining the process of cadastral value estimate of real estate. For instance, this function is performed by RosReestr register in Russia (Figure 2).

Fig.1. Budget revenue of Roseestr as of April 1, 2020, \%

We should note that merging the cadastral services, registration and appraisal organizations helps social development of land relations in a state through better government regulations of appraisal activities and the establishment of basic rules of cadastral value formation. At that, the updating time for the cadastral value should primarily be based on the country's inflation and be adjusted to the market trends taking into account that the appraisal should be independent. Property taxes are a significant source of budget revenue in most states. At the same time one should correlate the current economic situation and households' real disposable income, especially during the COVID-19 pandemic when regulating the cadastral value, which is of a direct influence on the size of the property tax object. There is no doubt that in the current stage of economic development of the states and the current tax payer's situation maintaining a balance of interests of the government and all economic subjects is important. 


\section{REFERENCE LIST}

Aghaei, I. and Sokhanvar, A. (2020). Factors influencing SME owners' continuance intention in Bangladesh: a logistic regression model. Eurasian Business Review, vol. 10, p. 391-415

Akhmadeev, R., Redkin, A., Glubokova, N., Bykanova, O., Malakhova, L. and Rogov, A. (2019). Agroindustrial cluster: supporting the food security of the developing market economy. Entrepreneurship and Sustainability Issues, vol. 7(2), p.1149-1170.

Akhmadeev, R.G., Bykanova, O.A. and Salomadina, P.S. (2019). The effect of the VAT change on the final consumer. Proceedings of the 33rd International Business Information Management Association Conference, IBIMA 2019: Education Excellence and Innovation Management through Vision 2020, p.765-770.

Avvakumova, I.V., Bykanova, O.A. and Akhmadeev, R.G. (2020) Improvement of small business owners taxation. In the Proceedings of the 7th International Conference on Education and Social Sciences (INTCESS) p. 532-537

Bliemer, M., Raadsen, M., Brederode, L., Bell, M., Wismans, L. and Smith, M. (2017) Genetics of traffic assignment models for strategic transport planning. Transport Reviews. vol. 37(1), p. 56-78

Chaykovskaya, L.A., Turishcheva, T. B. and Akhmadeev R. G. (2020). Functional application of the internal control system in autonomous institutions. Bulletin of the National Academy of Sciences of the Republic of Kazakhstan. vol. 1 (383), p. $163-171$.

Dück, H., Eufinger, A., Schultes, M. (2017) Company networks in the light of European market power. Business Networks Reloaded, 260-277.

Dück, H., Heene, J. (2015) "Made in Germany" as a quality feature in medicine. Medizinrecht, 33 (2): 101106.

Golubtsova, E.V. and Zvereva, A.O. (2019) Development of Tax Attractiveness of Russia's Special Administrative Areas with Fair Tax Competition. Proceedings of the 34th International Business Information Management Association Conference, IBIMA 2019: Education Excellence and Management of Innovations through Sustainable Economic Competitive Advantage Vision 2025, p. 2023- 2028

Golubtsova, E.V. and Zvereva, A.O. (2019) Expediency of parallel import legalization in Russian Federation. Proceedings of the 33rd International Business Information Management Association Conference, IBIMA 2019: Education Excellence and Innovation Management through Vision 2020, p. 782-787.

Gorlanov, S., Medelyaeva, Z., Malitskaya, V., Chirkova, M. and Kostyukova, E. (2019) Content analysis the term "effectiveness" and the concepts of its quantitative characteristics. Indo American Journal of Pharmaceutical Sciences. vol. 6 (3), p. 5293-5298.

Kalacheva, O. N. (2019) A Survey of Modern E.U. Approaches towards Amortization Policies. Proceedings of the 34th International Business Information Management Association Conference, IBIMA 2019: Education Excellence and Management of Innovations through Sustainable Economic Competitive Advantage Vision 2025, p. 4515 - 4522

Moeslund, J.E., Arge, L. and Bocher, P.K. (2011) Geographically Comprehensive Assessment of SaltMeadow Vegetation-Elevation Relations Using LiDAR. Wetlands. vol. 31, p. 471-478

Morozova, T. and Lehoux, L. (2019) Practical Aspects of Useful Life Calculation for Fixed Assets in IFRS Reports. Proceedings of the 34th International Business Information Management Association Conference, IBIMA 2019: Education Excellence and Management of Innovations through Sustainable Economic Competitive Advantage Vision 2025, p.4722-4729

Morozova, T., Akhmadeev, R., Lehoux, L., Yumashev, A., Meshkova, G. and Lukiyanova, M. (2020). Crypto asset assessment models in financial reporting content typologies, Entrepreneurship and Sustainability Issues, vol. 7(3), p.2196-2212.

Turishcheva T., Akhmadeev R., Bykanova O. and Nastasyuk N. (2020) Methodological Support for Internal Control of Autonomous Institutions. International Journal of Applied Exercise Physiology. vol. 9 (4), p. 53-61

Voronova, T. A., Golubtsova, E., V., Maksimov, D. A., Novikova, E. S. and Ponomareva, N., V. (2020) The 
Role of Taxation in the Competitiveness of Russian Education Following Globalization and Digitalization Processes in the World Economy. Turismo Estudos \& Práticas, vol. 2, p. 1-7

Wang, C., Pouliot, J. and Hubert, F. (2017) How users perceive transparency in the 3D visualization of cadastre: testing its usability in an online questionnaire. Geoinformatica. vol. 21, p. 599-618.

Zaporozhtseva, L., Malitskaya, V., Chirkova, M., Tkacheva, Y. and Kuznetsova, I. (2020). Financial mechanism for commercial organization development: vector approach. International Transaction Journal of Engineering, Management \& Applied Sciences \$ Technologies, vol. 11 (7), p. 1021-1032.

Zvereva, A.O., Golubtsova, E.V. and Tsilikova, M.S. (2020) The specifics of the use of tax instruments in the digital trade of the Russian Federation. In the Proceedings of the 7th International Conference on Education and Social Sciences (INTCESS), p. 44-50 